\title{
Challenges of Citizen Elections Observation in Nigeria: A Historical Perspective
}

\author{
Greene Ifeanyichukwu Eleagu, Ph.D
}

Political Science Department, Gregory University, Uturu, Abia State, Nigeria Gloria Obiageri Eleagu,

Department of Social Studies, Alvan Ikoku Federal College of Education, Owerri, Imo State, Nigeria

Doi:10.19044/esj.2019.v15n29p51～URL:http://dx.doi.org/10.19044/esj.2019.v15n29p51

\begin{abstract}
The near six decades of Nigeria as an independent nation has been fraught with instability arising essentially from attempts at democracy through periodic elections. These elections have been largely chacterized by hooliganism, ballot-snatching, theft of election materials, kidnapping of political opponents, assassination of political rivals, arson, assault and physical destruction of election materials and even intimidation and outright molestation or killing of election officials. This paper therefore went down the memory lane to establish and, using the Marxist theory of state attempt to explain, the pattern of elections that have characterized democracy in Nigeria and locate the place of citizen observers in Nigerian elections.
\end{abstract}

Keywords: Election, Democracy, Citizen observation, Opposition, Violence

\section{Introduction}

Periodic elections have, generally, become a major index for measuring democratic compliance and soundness across the globe. According to Bratton and Posner (1999:378) elections provide the best criterion for orderly leadership succession, entailing popular participation. They ensure responsibility and responsiveness on the part of government. According to the United Nations (cited in Wanyonyi, 1997: 21), “... the will of the people shall be the basis of authority of government. This shall be expressed in periodic and genuine elections...". Not a few argue that sound democratic practice depends greatly on respect for civil rights and due process of law. And so countries lacking in democratic principles are labelled pariah states.

According to Fischer (2002:2) "An electoral process is an alternative to violence as it is a means of "which is a product of interaction" (Marco, 2006:13). Marco said it "is inevitable and therefore must always erupt in any 
society at various magnitudes...". Various attempts in Nigeria at democracy through elections have only succeeded in providing battle grounds for hooliganism, ballot-snatching, theft of election materials, kidnapping of political opponents, assassination of political rivals, arson, assault and physical destruction of election materials and even intimidation and outright molestation or killing of election officials.

Nigeria has a long history of electoral violence and makes it a target for closer scrutiny or observation (Eleagu, 2016). Even the pre-independence 1959 federal elections designed by the British to midwife the transition from colonial rule to independence was fraught with violence. The antagonistic positions assumed by the two major alliances of political groups, i.e., Nigerian National Alliances (NNA) and United Progressive Grand Alliance (UPGA) meant that no matter which one of the two groups won, the results will be hotly contested. (Godowoli 2003:97). As was expected, allegations of manipulation of electoral laws and process by the ruling party (NPC) brought about a call for boycott of the elections by the opposition.

The first post-independence general elections in Nigeria took place in December 1964 "and was marred by violence and corruption" (Commonwealth Observers Group,2007:5) and did not fare any better in terms of electoral violence. And so the 1964 general elections results were rejected by the opposition, especially in the Western region where they resorted to violence to contest what they perceived as stealing of their mandate by the ruling NPC. What followed was complete breakdown of law and order or operation wetie, earning the region the inglorious reference as the Wild Wild West. This afforded the federal government an opportunity to declare a state of emergency in the region. The Western regional crisis found strength in the "1960/64 census disputes" (Setedu,2005) and along with other factors led to the 1966 military coup and the subsequent civil war in 1967 that lasted until 1970.

Since independence in 1960 "Nigeria has had a tumultuous political history,....experiencing a succession of military coups" (Commonwealth Observers Group, 2007:4). Indeed by 1964, less than four years as an independent nation, Nigeria had its general elections which "were marked with massive rigging; conflict and political violence of high degree, which culminated in the military takeover of power in 1966" (Mudasiru, 2005:476).

Nigerians again went to the polls in 1979, producing the civilian government of Alhaji Shehu Shagari which, as it started its second term in 1983, was overthrown on December 31, 1983 through a military coup by General Muhammadu Buhari. In August of 1985 the military once again took over the political space in Nigeria through a bloodless coup of by General Ibrahim Babangida (IBB) which overthrew General Muhammadu Buhari. Babangida repealed the decree on press censorship (Commonwealth 
Observers Group:3) and released former President Shehu Shagari and his vice, Dr. Alex Ekwueme, from detention.

It was, however, criticisms galore between 1985 and 1992 as the Ibrahim Babangida regime was accused of countless misdeeds, including linking it with the letter bomb that killed Dele Giwa, editor of a critical news magazine. Civil society groups rose in defence of democracy. The violence that was scarce during the 1993 elections then surfaced around the June 12 date that Abiola held on to in pursuit of his mandate (Commonwealth Observers Group, 2007).

General Babangida organized Presidential elections for 12 June 1993 that proved controversial... Provisional results suggested that the Yoruba businessman, Chief Moshood Abiola, had a clear lead over his rival, Alhaji Bashir Tofa, however, on 23 June 1993 the ruling National Defence and Security Council (NDSC), which had replaced the AFRC, annulled the elections before the full results could be announced by the National Electoral Commission (NEC), which was itself suspended. Chief Abiola continued to claim, nevertheless, that he had been duly and legitimately elected. Over 100 people were killed in riots protesting the decision to annul the election. General Babangida announced that there would be a new presidential election on 27 August, but this was greeted by general disbelief and the Social Democratic Party (SDP) announced that it would boycott the election. (Commonwealth Observers Group:5)

Following the annulment of the widely perceived free and fair elections in 1993 the Group continued noted that protests broke out, including strikes. General Babangida "stepped aside" under pressure from various quarters,

handing power on 27 August 1993 to an Interim National Government headed by Chief Ernest Shonekan, a non-partisan businessman who promised to supervise the organization of fresh elections that were scheduled for early 1994. However, on 17 November 1993 Chief Shonekan was removed from office and General Sani Abacha, the Minister of Defence, took over. The next day General Abacha announced the dissolution of all organs of state and bodies established under the previous transition programme (p6).

Precisely in June 1994 Chief M.K.O. Abiola was arrested and charged with treason for forcefully declaring himself president of Nigeria. Abiola and his supporters had gathered at Tafawa Belewa Square in Lagos where he declared himself winner of the 1993 presidential election. Many prodemocracy groups, including National Democratic Coalition (NADECO) 
chieftains were arrested and jailed for supporting the protests. Some of them fled the country. The Commonwealth Group observed further that

The government took strong action against its other perceived opponents. In July 1994 it dissolved the elected executive council of the two main petroleum trade unions - the National Union of Petroleum and Natural Gas Workers (NUPENG) and the Petroleum and Natural Gas Senior Staff Association (PENGASSAN) - replacing them with government appointees. The leaders of the two associations were later arrested and detained. In March 1995, former Head of state Chief Obasanjo and his former deputy, General Shehu Musa Yar'Adua and several others, were arrested in connection with an alleged coup plot. Chief Obasanjo was subsequently sentenced to life in prison (later commuted to 25 years imprisonment) while Yar'Adua and 12 others received the death sentence (later commuted to life imprisonment). General Yar'Adua later died in custody in suspicious circumstances (p6).

The military Provisional Ruling Council executed Ken Saro-wiwa and eight other Ogoni activists on November 10, 1995 after a trial by special tribunal on charges of complicity in the murder of four local chiefs. This was in spite of many international appeals for clemency and assurances given by the Nigerian government to several prominent Commonwealth leaders to the effect that it would not proceed with the executions. The executions coincided with the Commonwealth Heads of governments meeting in Auckland, New Zealand. An immediate consequence of the executions was the suspension of Nigeria from the Commonwealth. In a bid to reduce international hostile attitude towards his regime General Sani Abacha initiated a transition programme.

Its sole aim was to achieve his own legitimization. Only five political parties were approved by his regime, and all five adopted him as their presidential candidate for elections that were to be held in October 1998. However, General Abacha died suddenly on 8 June 1998 and was succeeded by General Abubakar, formerly Chief of Defence staff (Commonwealth Observers Group,2007:6).

The Commonwealth Observers Group (2007:6) noted that "General Abubakar released those accused of involvement in coup attempts (including Chief Obasanjo) and repealed many military decrees which had severely impinged on human rights. Sadly, Chief Moshood Abiola died on the eve of release from detention on 7 July 1998'. General Abdulsalami Abubakar's regime midwifed the 1999 elections that produced a former military head of state, retired General Olusegun Obasanjo of the Peoples Democratic Party 
(PDP), as the winner and new president of Nigeria. While his democratic administration lasted Obasanjo declared every May 29 as Democracy Day, a holiday in Nigeria to mark the return of democracy in Nigeria. The next elections year in Nigeria was 2003 and was special in that it marked the first attempt by a democratic regime to conduct elections following the exit of the military.

By 1999 Nigeria recorded a shift from military rule to democratic government. And so "By the date of the 2007 state and national elections, the country had already recorded success in achieving an unprecedented eight years of uninterrupted democratic rule" (Chukwuma,2007:14).Again the lesson of the pre-military era seemed lost on the politicians as the Labour Electoral Monitoring Team in Nigeria noted that:

These days many politicians seek power with the aim of promoting primitive accumulation. Politics is now seen as a vehicle for making quick and easy money. This rents seeking and rent collection mentality of politicians can be seen from the desperation of incumbents to hold on to power by any means. The counter weight to this is the determination and the desperation of the elites outside to get into power by any means necessary. To these elites the end result of getting control of political power is justified by whatever means is employed. This means include violence (LEMT, 2003:89)

Not a few see politics as a means for self service in Nigeria today, being the surest, quickest, easiest and most rewarding avenue for escaping the growing poverty to which most Nigerians are today condemned. Such survival strategy connotes winner takes all syndrome. Political exclusion, therefore, accounts for the use of illegitimate means to ensure success at the polls. Electoral violence is one of such illegitimate means. Electoral violence, which is a consequence of electoral inadequacies, can also be seen as a means of perpetrating electoral injustice. A violent electoral environment gives room for hijacking of the entire electoral process. Consequently elections become a smokescreen or window dressing for stage-managing transitions in Nigeria. As TMG coordinator noted "the 2007 elections, unfortunately like most electoral contests in Nigeria, assumed the features of warfare rather than open and civil competition for political power" (Chukwuma,2007:6,7).

The propensity of elected officers in Nigeria to tamper with public funds with near impunity has made the desire for government or elected offices to skyrocket. Even Nigerians in Diaspora who spot the Nigerian government officials on shopping sprees overseas are attracted to return and contest for even local government chairmanship elections. Of course, they are often rigged out even at the party primaries. 
Institutions abound in Nigeria to ensure free and fair elections. These include Independent Electoral Commission (INEC), Department of State Security (DSS), Economic and Financial Crimes Commission (EFCC), the police, army, the electoral tribunals and even election monitors and observers. However, concerning the 2007 elections TMG (Chukwuma,2007) also noted that "state institutions such as INEC and EFCC saddled with the responsibility of conducting free and fair elections and sanitizing the polity, failed woefully in their respective tasks."

\section{Citizen Election Observation in Nigeria}

However, it was not until 1998, with the coming of Transition Monitoring Group (TMG) that election observation came into being in Nigeria. This was made possible by the identification and application of such international and local instruments as the Universal Declaration of Human Rights of 1948, the African Charter, and the Nigerian Constitution of 1979, among others. Some have argued that while observation only entails recording of events and deviations therein and making same public or available to the institution or election body concerned, monitoring goes further to involve authority to correct the observed infractions. Therefore, though the name suggests monitoring the TMG was actually involved in election observation, as INEC has always insisted that only it (INEC) has the powers to respond to any observed anomaly in an election process, and so all others are mere observers. Following in the footsteps of the TMG in other elections are JDPC, ACE, FOMWAN, etc.

\section{Justification for Observation}

1. Right to know. This stems from the right to freedom of expression which entails right to hold and canvass opinion.

2. Intra-party squabbles and bickering. This is usually widespread and demands scrutiny by independent observers.

3. Political godfatherism. The political space is fraught with undue interference by political god fathers who use their successors as puppets and conduits for siphoning public funds.

4. Political violence. As noted earlier are hardly devoid of violence, rancour, acrimony, and bickering.

5. Election fraud. Several post-election findings suggest fraud as a recurring decimal in elections in Nigeria.

6. Weak institutions. To further compound the matter is the absence of strong institutions that can defend democracy in Nigeria.

7. Public funds. Elections are heavily funded by the state in Nigeria. Other sources of funding are the international donor agencies. All these call for non-partisan monitoring by local or citizen observers. 
Thus, it is the task of this paper to $\mathrm{x}$-ray, in a historical perspective, challenges of citizen elections observation in Nigeria.

\section{Theoretical Framework}

This study adopts the Marxist theory of state as its preferred framework for analysis. This school of thought has "three different perspectives" (Onuoha: 2003:202). These include the instrumentalists (those who see the state as an instrument in the hands of the ruling class) who see the state as a mere passive tool in the hands of a powerful ruling class. The proponents of this theory consider the state a lifeless entity that has no independent will. Marx and Engels argued in the communist manifesto of 1864 "that the executive is but a committee for managing the common affairs of the whole bourgeoisie', A second perspective sees in the state a power towering above the society and moderating as well as mediating inter- and intra-class conflicts while the institutionalists provide the third perspective which views the state as a concrete institution or institutional mechanism serving the dominant interest, not necessarily the interest of the whole nation.

The centrality of the state as an instrument of bourgeois oppression and exploitation and the unrepentant attempts by politicians to gain and control state power thus provides a prism for understanding how elections have served democracy in Nigeria. This tallies with the second view which sees the state as a towering power to reconcile intra- and inter-class conflicts in elections and democracy in Nigeria.

\section{Findings}

The lust for state power by the bourgeoisie or ruling class using the agents of state to rig elections, stuff ballot boxes, hire gangsters and marginalize the masses prepared the way for rise in electoral violence in the period of this study. Sometimes the ruling class achieved this situation by inaction or poor actions as when voting did not take place but results were announced or voting materials arrived too late for any fairness to be guaranteed.

INEC particularly started failing by shoddy preparation of voters' register claiming that the introduction of Electronic Voters Register came with teething problems. Again, TMG noted that ballot papers were printed without traceable numbers while INEC officials could not exert strict control regarding their distribution. The statutory display of Voters Register and possible supplementary Register were not strictly observed by INEC (See section 20 of the Electoral Act, 2006). Continuing the group observed that "security agencies that were deployed on election duties. . .connived with enemies of state not only to rob Nigerians of their mandate at gun point, but mercilessly killed and maimed the electorate in their hundreds". One of the ugly 
consequences of these lapses and irregularities was electoral violence resulting from the do-or-die attitude of the politicians.

1. Citizen observers' results are hardly relied on in court cases.

2. The citizen observers are almost always shabbily treated by the INEC, police and other security agencies, as against the royal diplomatic treatment accorded the foreign observers who sit in 5-star hotels in Abuja and state capitals to write, as results, whatever would protect their national interests. A prominent indictment of these international observers was the recent August 08, 2017 Kenyan presidential election which the foreign observers adjudged free, fair and credible, but which the Kenyan supreme court later annulled and ordered a fresh presidential vote within 60 days'. This was happening in a country known for electoral fraud and violence. Indeed " a disputed 2007 presidential vote sparked violence that killed around 1,200 people and displaced around 600,000 more''(https://www.independent.co.uk of 20 Sep 2017).

A critical analysis of available data and literature revealed that there is a general agreement among scholars that elections in Nigeria are prone to violence before, during and after elections. Thus, the issue of electoral violence is as old as the nation.

\section{Conclusion}

This paper dwelt on challenges of citizen elections observation in Nigeria. Central to the entire argument is the fact that, in spite of plethora of instruments empowering local observation, the huge efforts made and risks taken by citizen or local observers, their findings rarely count at any level in the Nigerian electoral process.

\section{Suggestions}

For elections to be true reflections of the will of the people local observers must be given pride of place. Their findings must be made to count in the adjudication of election petitions. The citizen observers must be given level observation ground as the foreign observers. They should be accorded more respect and protection by the security agencies. On their part, the citizen observers must always be neutral and objective in their observations. That way Nigeria will be better placed to have freer, fairer and more credible elections, reflective of the will of the majority of the Nigerian electorate.

\section{References:}

1. Babangida, Ibrahim, Quoted in Odofin A.P (2005), Electoral Politics, Elite Conspiracy and The Future Of Nigeria, in Godwin Onu and 
Abubakar Momoh(eds), Elections and Democracy Consolidation in Nigeria , Lagos Nigerian Political Science Association.

2. Bratton, Michael and Posner Daniel, (1999) "A First look at Second Elections in Africa with illustrations from Zambia", Richard Joseph (ed) State, Conflict and Democracy in Africa, Boulder: Lynne Reiner.

3. Chukwuma, Innocent, An Election Programmed To Fail: Final Report On the April 2004 General Elections in Nigeria:Abuja, Transition Monitoring Group.

4. Eleagu, Greene Ifeanyi (2016). "Electoral Violence in Nigeria: A Revisit of the April 14, 2007 Gubernatorial Election in Abia State", University of Nigeria Journal of Political Economy,Vol.9,No.2.pp 234-251.

5. Electoral Act 2006,Abuja,Electoral Reform Network.

6. Godowoli, A. H. (2003): "Electoral Violence and the Democratisation Project: The Nigeria Experience," in Olasupo B. A. (ed.) Electoral Violence in Nigeria Issues and Perspectives, Fredrick Ebert Stiftung (FES)

7. (https://www.independent.co.uk of 20 Sep 2017.

8. Jeff, Fischer (2002), Electoral Conflict and Violence, A Strategy for Study and Prevention, IFES White Paper (Jeff @ifes.org)

9. Labour Election Monitoring Team (2003) Nigeria; Balloting for Democracy, A report of the 2003 General Elections. Abuja; NLCLEMT.

10. Marco, Derrick (2006), Conflict Tracking Dossier, Toward the 2007 Elections, A Quarterly Review. Abuja: Idasa.

11. Mudashiru, Surajudean Oladosu, (2005), Political conflict and the 2003 General elections, in Onu Godwin and Abubakar Momoh (eds), Elections and Democratic Consolidation in Nigeria, Lagos: Nigerian Political Science Association.

12. NDI and Carter, November, 2002, First Statement, Abuja.

13. Onuoha, J. (1992) What is The State? Enugu: Acena Publishers.

14. Seteolu,Dele, 2005, Historical Trajectories of Elections in Nigeria: The State political Elite and Electoral Politics in Onu Godwin and Abubakar Moshood,(eds), Elections and Democratic Consolidation in Nigeria, Lagos: Nigerian Political Science Association.

15. Wanyonyi, Pius K., (1997), "A Historical Reflection on the Electoral Process in Post-Colonial Africa." Oyin Ogunba, (ed), Governance and the Electoral Process: Nigeria and the United states of America, Lagos: ASAN. 